\title{
3 \\ Copyright as an access right: Securing cultural participation through the protection of creators' interests
}

Christophe Geiger $^{1}$

It is never too late to give up our prejudices. No way of thinking or doing, however ancient, can be trusted without proof. What everybody echoes or in silence passes by as true today may turn out to be falsehood tomorrow, mere smoke of opinion, which some had

1 Professor of Law, Director General and Director of the Research Department of the Centre for International Intellectual Property Studies (CEIPI), University of Strasbourg; Affiliated Senior Researcher, Max Planck Institute for Innovation and Competition, Munich; and Spangenberg Fellow in Law \& Technology at the Spangenberg Center for Law, Technology \& the Arts, Case Western Reserve University School of Law, Cleveland, US. This paper draws for some parts on previous research published by the author on the social function of intellectual property and the relationship between human rights and copyright, in particular: 'The Social Function of Intellectual Property Rights, Or how Ethics can Influence the Shape and Use of IP law' in GB Dinwoodie (ed), Intellectual Property Law: Methods and Perspectives (Edward Elgar, 2014) 153; “"Constitutionalising" Intellectual Property Law?, The Influence of Fundamental Rights on Intellectual Property in Europe' (2006) 37(4) International Review of Intellectual Property and Competition Law, 371; 'Flexibilising Copyright - Remedies to the Privatisation of Information by Copyright Law' (2008) 39(2) International Review of Intellectual Property and Competition Law, 178; 'Implementing Intellectual Property Provisions in Human Rights Instruments: Towards a New Social Contract for the Protection of Intangibles' in C Geiger (ed), Research Handbook on Human Rights and Intellectual Property (Edward Elgar, 2015), 661. The author is thankful to Elena Izyumenko, PhD Candidate at the CEIPI, for her great research assistance and editorial support. 
trusted for a cloud that would sprinkle fertilizing rain on their fields. What old people say you cannot do, you try and find that you can. Old deeds for old people, and new deeds for new.

Henry David Thoreau, Walden; or, Life in the Woods, Boston, Ticknor and Fields, 1854, p 11.

\section{Introduction}

Copyright, originally conceived as a tool to protect the author and to provide incentives for him to create for the benefit of society, is nowadays more and more perceived as a mechanism to the advantage of 'large, impersonal and unlovable corporations'. ${ }^{2}$ As the results of a major recent study on the intellectual property (IP) perceptions of Europeans demonstrate, more than 40 per cent of EU citizens, when asked who benefits the most from IP protection, mention large companies and famous artists, ${ }^{3}$ and not creators or the society at large.

The inherent social dimension of copyright law has hence progressively been lost of sight by policymakers to the benefit of strictly individualistic, even egotistic conceptions. In the recent discourse on the strengthening of legal means of protection, copyright is more frequently presented as an investment-protection mechanism ${ }^{4}$ than a vehicle of cultural and social progress. In this context, the society's enrichment and future creativity are often portrayed in the rhetoric of the major economic players only as 'a fortunate by-product of private

2 JC Ginsburg, 'How Copyright Got a Bad Name for Itself' (2002) 26(1) Columbia Journal of Law \& the Arts 61, 61.

3 'European Citizens and Intellectual Property: Perception, Awareness and Behaviour' (OHIM Report, November 2013) 66.

4 See e.g. M Vivant, 'Propriété intellectuelle et nouvelles technologies, À la recherche d'un nouveau paradigm' in Université de tous les savoirs (Odile Jacob, 2001) vol 5: Qu'est ce que les technologies? 201 et seq. This conclusion can equally be reached for patent law, where the protection of creativity and innovation seems to become subordinate to the protection of investment. As B Remiche, 'Marchandisation et brevet' in M Vivant (ed), Propriété intellectuelle et mondialisation (Dalloz, 2004) 127, correctly emphasises, we have been witnessing for several years a change in the centre of interest of the law 'turning from the inventor's person to the investing company'. This change of paradigm can already be considered worrying since the perception of investment does not contain any human or ethical dimension. Compensation of the investment is not systematically a synonym for progress, and as Professor Remiche recalls, 'to accent the investment - or even to make the nearly single element out of it - means to incite the research and the investment only there where they are the most cost-effective and profitable!' (at 128). The interest of society cannot be reduced to economic interest; the social justification for intellectual property is larger and should take into account certain fundamental values. 
entitlement'. ${ }^{5}$ A good example of this discourse can be found in the huge advertisement campaigns that were launched a few years ago by the music industry, showing young internet users behind bars for having engaged in music file sharing and using classical analogy with the theft of tangible goods, according to which illegal downloading amounts to going into a shop and stealing. ${ }^{6}$ This has provoked some important counter-reactions: as copyright is perceived mainly as a right to forbid, to sanction and punish, infringing copyright has evolved, predominantly among the young generations, to an act of protest, ${ }^{7}$ leading to a serious crisis of legitimacy. ${ }^{8}$ Even among creators, copyright is increasingly perceived as a hurdle in the creative process, as the success of so-called 'open content' models clearly demonstrates.

These developments urgently attest the need to rethink copyright in order to adapt its rules to its initially dual character: 1) of a right to secure and organise cultural participation and access to creative works (access aspect); and 2) of a guarantee that the creator participates fairly in the fruit of the commercial exploitation of his works (protection aspect). Avoiding the privatisation of information by copyright law ${ }^{9}$ and assuring that cultural goods are still available for future innovations

5 CJ Craig, 'Locke, Labour and Limiting the Author's Right: A Warning against a Lockean Approach to Copyright Law' (2002) 28 Queen's Law Journal 1, at 14-15.

6 On this rhetoric, see more generally PL Loughlan, "“You Wouldn't Steal a Car ..." Intellectual Property and the Language of Theft' (2007) 401 European Intellectual Property Review.

7 'European Citizens and Intellectual Property', above n 2, 55.

8 Further on this crisis, see e.g. N Kroes, Vice-President of the European Commission responsible for the Digital Agenda from 9 February 2010 until 1 November 2014, 'Our Single Market is Crying Out for Copyright Reform', Speech delivered at the opening of Information Influx, the 25th anniversary International Conference of the Institute for Information Law (IViR), Amsterdam, 2 July 2014 (European Commission - SPEECH/14/528): ‘Every day citizens ... across the EU break the law just to do something commonplace. And who can blame them when those laws are so ill-adapted ... Technology moves faster than the law can, particularly in the EU. Today, the EU copyright framework is fragmented, inflexible, and often irrelevant. It should be a stimulant to openness, innovation and creativity, not a tool for of obstruction, limitation and control.'

9 Further on this tendency, see C Geiger, 'Flexibilising Copyright - Remedies to the Privatisation of Information by Copyright Law' (2008) 39(2) International Review of Intellectual Property and Competition Law, 178. 
might mean (re)conceiving copyright as an 'access right', ${ }^{10}$ and not as the right to forbid, exclude or sanction, thus emphasising the inclusive rather than the exclusive nature of copyright protection. ${ }^{11}$

Before turning to the consequences of such an understanding for the shape and use of copyright law (II), it will however be necessary to examine, first, the rationales underlying the often neglected nature of copyright as an 'access right' (I).

\section{Rationales for copyright to be conceived as an access right}

\subsection{The social function of copyright law and the philosophical link with the common interest ${ }^{12}$}

Even though the demand for an access aspect of copyright has only been made for a relatively short time, the idea is not completely new. Already in the 13th century, the theologian and philosopher Thomas

10 The term 'access right' in the context of this chapter needs to be clearly differentiated from its past, diametrically opposite understanding. In fact, the term 'access right' has been used in previous scholarly work to describe the right to control, even forbid, access to copyright works, which resulted from technical protection measures (TPM) and their legal protection by copyright law: see e.g. JC Ginsburg, ‘From Having Copies to Experiencing Works: The Development of an Access Right in U.S. Copyright Law' (2003) 50 Journal of the Copyright Society of the USA, 113; T Hoeren, 'Access Right as a Postmodern Symbol of Copyright Deconstruction?' in JC Ginsburg and JB Besek (eds), Adjuncts and Alternatives to Copyright, Proceedings of the ALAI Congress June 13-17, 2001 (Kernochan Center for Law Media and the Arts, 2002), 360; T Heide, 'Copyright in the E.U. and the United States: What "Access Right"?' (2001) European Intellectual Property Review, 476; S Olswang, 'Accessright: An Evolutionary Path for Copyright in the Digital Era?' (1995) European Intellectual Property Review 215. See however for an interesting attempt to define and conceptualise the access right in the digital world, Z Efroni, Access- Right: The Future of Digital Copyright Law (Oxford University Press, 2011). This author distinguishes 'access rights' and 'rights to access' and proposes a stimulating 'theoretical framework for a discussion on an information property system based on the concept of access' (at Introduction, xxi).

11 On the idea of inclusivity in IP, see also G van Overwalle, 'Smart Innovation and Inclusive Patents for Sustainable Food and Health Care: Redefining the Europe 2020 objectives' in C Geiger (ed), Constructing European Intellectual Property: Achievements and New Perspectives (Edward Elgar, 2013) EIPIN Series, vol 1; S Dusollier, 'Du gratuit au non-exclusif: Les nouvelles teintes de la propriété intellectuelle' in Vers une rénovation de la propriété intellectuelle?, 30e anniversaire de l'IRPI (Litec, 2014) 29; and from the same author: 'The commons as a reverse intellectual property- from exclusivity to inclusivity' in H Howe and J Griffiths (eds), Concepts of Property in Intellectual Property Law (Cambridge University Press, 2013) 258.

12 Throughout this chapter, the philosophical notion of the 'common interest', reflecting the interests of society at large, will be preferred to the terms 'public interest'. The 'public interest' terminology has in fact been already heavily used in past copyright legal discourse, especially 
Aquinas expressed an opinion that 'positive right' (jus positivum) could be regarded as fair and legitimate only inasmuch as it aims at the common wellbeing: put differently, if the right fulfils its so-called 'social function'. This idea has been hereafter reiterated by many legal philosophers. ${ }^{13}$ It was first confined to the context of private law in general (1) and then extended more specifically to the sphere of intellectual property (2).

\subsubsection{The social function of law}

Balance is the key concept that lies behind the social function. If law is a question of balance, there cannot be an 'absolute' right that can be exercised in a totally self-reflective manner with no consideration for the consequences that this exercise involves. As has been aptly put by $\mathrm{Du}$ Pasquier, 'the role of the law is to assure the peaceful coexistence of the human group or, as is often said, to harmonise the activity of members of society. In a word, it is the basis for the social order, which could only be achieved through a balance between opposing interests'. ${ }^{14}$

In France, this idea was developed in the 1930s by Louis Josserand. So far as concerns the right to property, he wrote that 'there is no need to investigate deeply to notice that this right that claims to be unlimited involves, above all in the field of real estate, a multitude of obstacles, barriers, frontiers that restrain its movements and oppose its expansion.' He further adds: 'This is fortunate, since if this tyrannical

in common law countries, both as an argument to extend and to limit protection. See G Davies, Copyright and the public interest, (Sweet and Maxwell, $2^{\text {nd }} \mathrm{ed}, 2002$ ) 236, 'It is seen to be in the public interest that authors and other right owners should be encouraged to publish their works so as to permit the widest possible dissemination of works to the public at large ... Thus, while copyright protection is justified by the public interest, the States imposes certain limitations thereto, again in the public interest.' Thus, there is already an important legal background and understanding attached to this terminology, which does not favour the 'blue-sky thinking' encouraged by the editors of this volume when rethinking and redesigning copyright law. The terms 'public interest', when used in this chapter, will thus refer only to situations when this wording has been employed by legislators of courts (for example in quotes) or will be put in brackets.

13 Further on this, see C Geiger, 'The Social Function of Intellectual Property Rights, Or how Ethics can Influence the Shape and Use of IP law' in GB Dinwoodie (ed), Intellectual Property Law: Methods and Perspectives (Edward Elgar, 2014) 153.

14 C Du Pasquier, Introduction à la théorie générale et à la philosophie du Droit (Delachaux et Nestlé, $4^{\text {th }}$ ed, 1967), 19. See also JH Drake, Editorial Preface of R von Ihering, Der Zweck im Recht [Law as a Means to an End] (Boston Book Company, 1913) 188: 'Law is not the highest thing in the world, not an end in itself; but merely a means to an end, the final end being the existence of society.' 
right was left to itself, to its specific nature, it would invade everything and end up by destroying itself ${ }^{\prime}{ }^{15}$ In the field of contract law, this social concept has been more recently developed by a number of legal scholars. Denis Mazeaud, for example, advocates 'the definitive recognition of a principle of 'loyalty, solidarity and fraternity' as a main and guiding principle of contemporary contract law ${ }^{\prime}{ }^{16}$

In Germany, the theory of the social function of private law (Sozialbindung des Privatrechts) ${ }^{17}$ made its appearance at the end of the 19th century, subsequently becoming a fundamental principle of German private law. ${ }^{18}$ This theory insists on the idea that private rights are limited by social constraints. It underlines the social nature of the legal system and the function of private law, which is to regulate the relationships between individuals within society. The function of the legal system is thus to find a compromise between the interests of the individual and the interests of the community. It must, on the one hand, ensure the grant of subjective rights to individuals but at the same time, on the other hand, ensure that these are compatible with the interests of the rest of the community. The rights of the individual are not seen as an absolute right but rather as rights limited in social terms. This theory is implemented, moreover, in the extremely rich judicial practice developed on the basis of Section 242 of the German Civil Code concerning good faith - a general clause that in the hands of the judge has become a veritable balancing instrument. ${ }^{19}$

15 L Josserand, De l'esprit des droits et de leur relativité (Dalloz, $2^{\text {nd }}$ ed, 1939, re-edited 2006) 16.

16 D Mazeaud, 'Loyauté, solidarité, fraternité: La nouvelle devise contractuelle?' in L'avenir du droit, Mélanges en hommage à François Terré (Dalloz/PUF/Éditions du Jurisclasseur, 1999) 603.

17 Literally translated: 'The social bounds of private law'.

18 O Von Gierke, Die soziale Aufgabe des Privatrechts (Berlin, 1889; republished by Klosterman, 1943); J Kohler, Das Autorrecht, eine zivilrechtliche Abhandlung (Verlag von G Fischer, Jena, 1880), 41. On this theory, see more recently T Repgen, Die soziale Aufgabe des Privatrechts: Eine Grundfrage in Wissenschaft und Kodifikation am Ende des 19. Jahrhundert (Mohr Siebeck, 2001). 19 WF Ebke and BM Steinhauer, 'The Doctrine of Good Faith in German Contract Law' in $\mathrm{J}$ Beatson and D Friedman (eds), Good Faith and Fault in Contract Law (Clarendon Press/Oxford University Press, 1997) 171. 


\subsubsection{The social function of copyright law and the common interest}

The idea that copyright must serve a social function has its origins in the philosophy of the Enlightenment. ${ }^{20}$ It rests upon the idea that intellectual property law is the product of a type of 'social contract' between the author and society. ${ }^{21}$ According to this concept, copyright is justified because it encourages creativity. Society has a need for intellectual productions in order to ensure its development and cultural, economic, technological and social progress and therefore grants the creator a reward in the form of an intellectual property right, which enables him to exploit his work and to draw benefits from it. In return, the creator, by rendering his creation accessible to the public, enriches the community. Copyright law is hence 'conditioned' by the achievement of certain objectives and its use can be (or rather must be) measured in the light of the results obtained. This particularly strong focus on the interests of society very soon led numerous German scholars to extend the theory of the social function to intellectual property rights. ${ }^{22}$ Julius Kopsch as early as the 1920 s even evoked the idea of an 'increased' social function with respect to intellectual property. ${ }^{23}$

One key aspect that derives from the social function is thus that the objectives and conditions of the exercise of copyright should always be examined in the light of the interest of society and the common interest. However, what exactly is this common interest? Most of the time, this notion is closely related to utilitarian doctrines, but philosophically speaking, there are several different versions of Utilitarianism. ${ }^{24}$ Mireille Buydens identifies three different philosophical conceptions. ${ }^{25}$ In a first understanding, the common interest is the interest of the Nation/State (Aristotle, Hegel, Fichte): ${ }^{26}$ whatever the state defines

20 See, for example, A Strowel, Droit d'auteur et copyright, Divergences et Convergences (Bruylant/LGDJ, 1993), 86 et seq; C Geiger, Droit d'auteur et droit du public à l'information (Litec, 2004) 27 et seq; 'Copyright and Free Access to Information, For a Fair Balance of Interests in a Globalised World' (2006) European Intellectual Property Review, 366.

21 For more details on this issue, see Geiger, above n 19, 27 et seq.

22 Kohler, above n 17, 40; E Riezler, Deutsches Urheber- und Erfinderrecht (Schweitzer, 1909), 430.

23 J Kopsch, 'Zur Frage der gesetzlichen Lizenz' (1928) (1) ArchFunkR 201.

24 For a fascinating analysis in the context of intellectual property, see M Buydens, La propriété intellectuelle, Evolution historique et philosophique (Bruylant, 2012), 351.

25 M Buydens, 'L'intérêt général, une notion protéiforme' in M Buydens and S Dusollier (eds), L'intérêt général et l'accès à l'information en propriété intellectuelle (Bruylant, 2008), 1.

26 Ibid 8 et seq. 
as the common interest has to be reflected by law. In a second interpretation, the notion is understood in exactly the opposite way: the common interest is defined according to the particular interests of the individual (Bentham, Adam Smith, John Stuart Mill); ${ }^{27}$ from the sum of the individual interests, acting in their own advantage, emerges the common interest. The common interest is the one that maximises profits of the majority of individuals. The third understanding of the notion is Christian in its inspiration. The common interest is defined as the 'good of Mankind' (Thomas Aquinas, Hume); ${ }^{28}$ in this conception, the reference is the human being. The role of society is to define a framework for human development and happiness, according to universal human values (including immaterial benefits such as social cohesion, solidarity, education, health, culture, sustainable development, etc.). This common interest has to originate from the 'Human' and be implemented by legislators. The link to human rights is here easily made and it is therefore not surprising to find human rights and constitutional law obligations among the second category of rationales for copyright as an 'access right'.

\subsection{Copyright through the lens of international human rights law and domestic constitutional law}

The common interest rationales behind IP protection are envisaged in numerous international and regional human rights treaties and national constitutions worldwide. This is done, first, through incorporation of certain ${ }^{29}$ copyright aspects in the universally recognised right to culture and science ${ }^{30}$ (1.2.1). Second, the access aspect of copyright can be traced in likewise internationally binding 'expressive' foundations of IP (in accordance with which copyright is

\footnotetext{
27 Ibid 22 et seq.

28 Ibid 37 et seq.

29 Further on the distinction that exists between the standard IP rights and the human rights protection given to creators in accordance with the right to science and culture, see UN Committee on Economic, Social and Cultural Rights (CESCR), General Comment No. 17: The Right of Everyone to Benefit from the Protection of the Moral and Material Interests Resulting from any Scientific, Literary or Artistic Production of Which He or She is the Author (Art. 15, Para. 1 (c) of the Covenant), UN Doc E/C.12/GC/17 (12 January 2006); UN General Assembly, Report of the Special Rapporteur in the field of Cultural Rights, F Shaheed, Copyright Policy and the Right to Science and Culture, Human Rights Council, Twenty-eighth session, A/HRC/28/57, 24 December 2014.

30 See, on the international level, article 27 of the Universal Declaration of Human Rights (UDHR) (see below n 32) and article 15 of the International Covenant on Economic, Social and Cultural Rights (ICESCR) (see below n 34).
} 
to be regarded as an exception to the generic right to freely express oneself, impart and receive information $)^{31}$ (1.2.2). Finally, inclusion of copyright within the protection of property at constitutional level ${ }^{32}$ often guarantees that the social function of property is extended to intellectual property (1.2.3).

\subsubsection{Copyright as enabling an access to science and culture}

The best example of an access-safeguarding framework for copyright protection is offered by article 27 of the Universal Declaration of Human Rights (UDHR). ${ }^{33}$ According to its first paragraph, everyone has 'the right freely to participate in the cultural life of the community, to enjoy the arts and to share in scientific advancement and its benefits', while according to the second paragraph of the same provision, everyone has the right to the protection of the moral and material interests resulting from any scientific, literary or artistic production of which he is the author. ${ }^{34}$ Although it is true that the UDHR does not have a direct binding effect, the same does not apply to article 15(1) of the International Covenant on Economic, Social and Cultural Rights (ICESCR), ${ }^{35}$ adopting the wording of the UDHR almost verbatim. ${ }^{36}$ On the regional level, copyright is in a similar manner conceived as enabling access to science and culture in article 14 of the Additional

31 See article 19 of the UDHR and article 19 of the International Covenant on Civil and Political Rights (ICCPR).

32 At the international level, see article 17 of the UDHR. Note, however, that neither ICESCR nor ICCPR enshrine a similar guarantee of property within their human rights catalogues.

33 Universal Declaration of Human Rights, GA Res 217A, UN Doc A/810 (10 December 1948).

34 For further analysis of article 27 of the UDHR, see inter alia E Stamatopoulou, Cultural Rights in International Law: Article 27 of the Universal Declaration of Human Rights and Beyond (Martinus Nijhoff Publishers, 2007), 110.

35 International Covenant on Economic, Social and Cultural Rights, opened for signature 16 December 1966, 993 UNTS 3.

36 See, for further discussion of this provision, C Sganga, 'Right to Culture and Copyright: Participation and Access' in C Geiger (ed), Research Handbook on Human Rights and Intellectual Property (Edward Elgar, 2015), 560; L Shaver and C Sganga, 'The Right to Take Part in Cultural Life: On Copyright and Human Rights' (Winter 2010) 27 Wisconsin International Law Journal, 637; L Shaver, 'The Right to Science and Culture' (2010) (1) Wisconsin Law Review, 121. See also the forthcoming proceedings of international roundtable organised by the Centre d'Etudes Internationales de la Propriété Intellectuelle (CEIPI) on the topic 'Intellectual Property and Access to Science and Culture: Convergence or Conflict?', CEIPI, University of Strasbourg, 11 May 2015, especially the papers presented by Lea Shaver, Rebecca Giblin and Christophe Geiger, CEIPI-ICTSD publication series, number 3, Global Perspectives and Challenges for the Intellectual Property System, 2016. 
Protocol to the American Convention on Human Rights (ACHR) ${ }^{37}$ and article 13 of the American Declaration of the Rights and Duties of $\mathrm{Man}^{38}$ - the latter being in fact a precursor to the UDHR. ${ }^{39}$

The classical foundations of IP are placed in a stable balance in these international human rights instruments: on the one hand, the foundation of natural law by acknowledging an exploitation right and a 'droit moral' for the creator; and, on the other hand, the utilitarian foundation, because this acknowledgement has the promotion of intellectual variety and the spread of culture and science throughout society as a goal. ${ }^{40}$ Further, both the UDHR and the ICESCR emphasise the link to the 'author', namely the creator, also referring to the words such as 'he' and 'everyone', thereby excluding protection of the legal entities' entitlements on the level of human rights. ${ }^{41}$

So far as concerns the domestic constitutional level, an impressive number of national primary law instruments mirror the UDHR and the ICESCR in safeguarding creators' rights within the scope of the right to science and culture. ${ }^{42}$ Most of such clauses are characterised

37 Additional Protocol to the American Convention on Human Rights in the Area of Economic, Social and Cultural Rights ('Protocol of San Salvador'), Organization of American States, opened for signature 17 November 1988, OASTS 69 (ACHR).

38 American Declaration of the Rights and Duties of Man, Inter-American Commission on Human Rights, 2 May 1948, OAS Res XXX, adopted by the Ninth International Conference of American States, reprinted in Basic Documents Pertaining to Human Rights in the Inter-American System, OAS/Ser.L/V/I.4 Rev 9 (2003) ('American Declaration').

39 Since the discussed provisions of the UDHR, the ICESCR, the ACHR and the American Declaration closely correspond to each other, this paper mainly focuses on the provisions of only the UDHR and the ICESCR as instruments of universal coverage.

40 For further discussion of the classical foundations of IP law, see C Geiger, " Constitutionalising" Intellectual Property Law? The Influence of Fundamental Rights on Intellectual Property in Europe' (2006) 37(4) International Review of Intellectual Property and Competition Law371, 377 et seq.

41 See CESCR, above n 28, [7].

42 For examples of such constitutional provisions, see article 54(3) of the Constitution of the Republic of Bulgaria (1991); article 69 of the Constitution of the Republic of Croatia (1990); article 34(1) of the Czech Charter of Fundamental Rights and Freedoms (1993); article 113 of the Constitution of Latvia (1922); article 42 of the Constitution of the Republic of Lithuania (1992); article 43(1) of the Constitution of Slovakia (1992); article 42 of the Constitution of the Portuguese Republic (1976); article 36 of the Constitution of the Republic of Armenia (1995); article 44(1) of the Constitution of the Russian Federation (1993); article 73(2) of the Constitution of the Republic of Serbia (2006); article 58 of the Constitution of the Republic of Albania (1998); article 64 of the Constitution of the Republic of Turkey (1982); article 2(8) of the Political Constitution of Peru (1993); article 98 of the Constitution of the Bolivian Republic of Venezuela (1999); article I, section 8, clause 8 of the United States Constitution (1787); articles 125 and 127 of the Political Constitution of the Republic of Nicaragua (1987); article 29 of the Constitution of the Republic of the Congo (2002); article 46 of the Constitution of the Democratic Republic of Congo (2006); article 94 of the 
by a balanced wording, directly referring to the 'public interest' dimension of copyright. To give just a few examples, article 42 of the Lithuanian Constitution of 1992, for instance, ensures that the State 'supports culture and science' while 'protecting and defending the spiritual and material interests of an author which are related to scientific, technical, cultural, and artistic work' ${ }^{43}$ A similar wording is adopted by many other constitutions worldwide, including article 73 of the Constitution of Serbia of 2006, article 98 of the Constitution of Venezuela of 1999, article 46 of the Constitution of the Democratic Republic of Congo of 2006, and article 40 of the Constitution of Tajikistan of 1994. Nevertheless, perhaps the most famous constitutional provision, explicitly referring to the interests of society as a legislative motive behind copyright protection, is article 1 , section 8 , clause 8 of the US Constitution of $1787,{ }^{44}$ which reads as follows: 'The Congress shall have Power ... To promote the Progress of Science and useful Arts by securing for limited Times to Authors and Inventors the exclusive Rights to their respective Writings and Discoveries. $^{.45}$

The common interest considerations behind the grant of protection are made salient here: exclusive rights are conferred insofar and inasmuch as they facilitate cultural progress. The interests of society are a reason for granting protection but also a reason for limiting it - a premise that has been further interpreted and completed by the established judicial practice of the US Supreme Court. For instance, a decision dating from 1932 laid down that the 'sole interest of the United States and the primary object in conferring a monopoly lie in the general benefits

\footnotetext{
Constitution of the Republic of Mozambique (2004); article 26 of the Constitution of the Republic of Madagascar (1992); article 47 of the Constitution of the Islamic Republic of Afghanistan (2004); article 49 of the Constitution of the Kyrgyz Republic (2010); article 16 of the Constitution of the People's Republic of Mongolia (1992); article 22 of the Constitution of the Republic of Korea (1948); article 40 of the Constitution of the Republic of Tajikistan (1994); article 60 of the Constitution of the Socialist Republic of Vietnam (1992); Part 9, Section 86 of the Constitution of the Kingdom of Thailand (2007). For further discussion, see C Geiger, 'Implementing Intellectual Property Provisions in Human Rights Instruments: Towards a New Social Contract for the Protection of Intangibles' in C Geiger (ed), Research Handbook on Human Rights and Intellectual Property, (Edward Elgar, 2015).

43 Emphasis added. For an excellent analysis of the Lithuanian Constitutional Court's interpretation of article 42 intellectual property provision, see V Mizaras, 'Issues of Intellectual Property Law in the Jurisprudence of the Constitutional Court of the Republic of Lithuania' (2012) 19(3) Jurisprudence.

44 The so-called 'Progress Clause'.

45 Emphasis added.
} 
derived by the public from the labour of authors' ${ }^{46}$ In addition, the 'Progress-Clause' explicitly refers to 'authors' as beneficiaries of copyright protection, thereby reinforcing, on a constitutional level, the primary role of the creator.

\subsubsection{Copyright as an exception to freedom of expression}

In direct link with its capacity to enable cultural access is the constitutional perception of copyright as an integral part of the right to freedom of expression and information.

Since its inception copyright has maintained close links with freedom of expression and its corollary, the public's right to receive and impart information. ${ }^{47}$ In fact, the access to information and copyright fully converge regarding both the rationale and the principles involved. ${ }^{48}$

A good illustration of this convergence is article 20 of the Spanish Constitution of 1978, where IP is protected within the framework of the right to freedom of expression and information (paragraph $1(b)){ }^{49}$ As put succinctly by F Bondia in a comment on this provision:

46 Fox Film Corp v Doyal, 286 US 123, 127 (1932). Many cases reiterate the reference to the public interest and the public good. See, for example, Fogerty $v$ Fantasy Inc, 510 US 517, 526 (1994): 'We have often recognized the monopoly privileges that Congress has authorized, while "intended to motivate the creative activity of authors and inventors by the provision of a special reward," are limited in nature and must ultimately serve the public good' (referring to the landmark Sony Corp of America v Universal City Studios Inc, 464 US 417, 429 (1984), emphasis added). See also Harper \& Row Publishers Inc $v$ Nation Enterprises, 471 US 539, 558 (1985): 'The economic philosophy behind the clause empowering Congress to grant patents and copyrights is the conviction that encouragement of individual effort by personal gain is the best way to advance public welfare through the talents of authors and inventors in "Science and useful Arts"' (quoting Mazer v Stein, 347 US 201, 219 (1954), emphasis added); NY Times Co v Tasini, 533 US 483, 524 n 20 (Stevens J, dissenting) (2001): ‘Copyright law is not an insurance policy for authors, but a carefully struck balance between the need to create incentives for authorship and the interests of society in the broad accessibility of ideas' (emphasis added).

47 See Geiger, above n 19, 27 et seq.

48 On the double-sided nature of the right to freedom of expression, see an interesting document published recently by the Freedom of Expression on the Internet Initiative of the Center for Studies on Freedom of Expression and Access to Information, Freedom of Expression versus freedom of expression: Copyright protection invokes internal tension (Palermo University, 2013).

49 For further discussion of this provision, see JM Otero, 'La protección constitucional del derecho de autor: Análisis del artículo 20.1 b/ de la Constitución española de 1978' (1986) Part 2 La Ley 370. 
[f]reedom of expression belongs to intellectual property, as its lack kills artistic creativity, scientific research as well as the philosophical search for the truth. Besides, intellectual property is the river bed or the iter where freedom of expression passes by, and that is perfectly understood in our Constitution when it gathers both rights at the same legal article.. $.50^{50}$

In fact, one can infer from article 20 of the Spanish Constitution that the goal of IP is, at least partly, to guarantee freedom of expression and the public's right to information - a logic that could be traced further in article 15(e) of the Liberian Constitution of 1984, when it refers to 'the commercial aspect of expression in ... copyright infringement', and article 13 of the Central African Constitution of 2004, incorporating the protection of 'freedom of intellectual, artistic and cultural creation' within the broader right to freedom of expression and information.

Apart from domestic constitutions, in Europe, the European Convention on Human Rights (ECHR) codifies the principle of freedom of expression and communication in article $10(1),{ }^{51}$ while article 10(2) provides for restrictions in the protection of the rights of others, which include the rights of creators. ${ }^{52}$

This recognition of creators' rights as an exception to the general rule of freedom of expression protection dovetails with the recent case law of the European Court of Human Rights (ECtHR), the body in charge of interpreting and enforcing the ECHR. ${ }^{53}$ In particular, two

50 F Bondia, Propiedad intelectual. Su significado en la Sociedad de la Información (Trivium, 1988), 94, 105, cited in J Rodriguez, 'A Historical Approach to the Current Copyright Law in Spain' (2006) 28(7) European Intellectual Property Review 389, 393.

51 On the level of the EU, analogous guarantee of free expression protection is enshrined in article 11 of the EU Charter of Fundamental Rights, the scope and meaning of which are the same as of article 10 ECHR (see Note from the Praesidium, Draft Charter of Fundamental Rights of the European Union, Text of the Explanations Relating to the Complete Text of the Charter as set out in CHARTE 4487/00 CONVENT 50 (Brussels, 2000), 13-14).

52 On the cases in which copyright was considered as falling under the 'rights of others' within the meaning of article 10(2) European Convention on Human Rights (ECHR), see e.g. Neij and Sunde Kolmisoppi v Sweden (dec) (European Court of Human Rights, no. 40397/12, 19 February 2013); Ashby Donald and Others v France (European Court of Human Rights, no. 36769/08, 10 January 2013); Société Nationale De Programmes FRANCE $2 v$ France (dec) (European Commission of Human Rights, no. 30262/96, 15 January 1997); N V Televizier $v$ The Netherlands (report) (European Commission of Human Rights, no. 2690/65, 3 October 1968).

53 Further on this, see C Geiger and E Izyumenko, 'Copyright on the Human Rights' Trial: Redefining the Boundaries of Exclusivity Through Freedom of Expression' (2014) 45(3) International Review of Intellectual Property and Competition Law 316. 
important rulings from the Court rendered in 2013, Ashby Donald ${ }^{54}$ and 'The Pirate Bay', ,5 clearly demonstrated the major change of perspective on copyright as being traditionally regarded immune from any external freedom of expression review. In both cases the ECtHR held that the use of a copyrighted work could be considered as an exercise of the right to freedom of expression, even if the use qualifies as an infringement and is profit-motivated. Therefore, by verifying if in the given situation the interference can be justified with regard to other conflicting rights, the ECtHR advanced the idea that freedom of expression has to be considered as the point of departure and that no predetermined answer can be given by copyright law. ${ }^{56}$ This goes in line with the freedom of expression-compliant principle that the exclusive right constitutes an exception to a broader principle of freedom of use. ${ }^{57}$

\subsubsection{Copyright as property - extension of the social function}

Apart from article 10, there is however yet another provision under the ECHR that can help to fill the missing link between copyright protection and its 'public-interest' justifications. Article 1 of the First

54 Ashby Donald and Others v France (European Court of Human Rights, no. 36769/08, 10 January 2013); Comment, 'Ashby Donald and others $v$ France' (2014) 45(3) International Review of Intellectual Property and Competition Law 354; P Torremans, 'Ashby Donald and others $v$ France, application 36769/08, EctHr, $5^{\text {th }}$ section, judgment of 10 January 2013' (2014) 4(1) Queen Mary Journal of Intellectual Property 95.

55 Neij and Sunde Kolmisoppi v Sweden (dec), (European Court of Human Rights, no. 40397/12, 19 February 2013); Comment, 'Pirate Bay' (2013) 44(6) International Review of Intellectual Property and Competition Law 724. For a comment, see J Jones, 'Internet Pirates Walk the Plank with Article 10 Kept at Bay: Neij and Sunde Kolmisoppi v Sweden' (2013) 35(11) European Intellectual Property Review 695.

56 For a joint comment of Ashby Donald and 'The Pirate Bay', see Geiger and Izyumenko, above n 52. See also D Voorhoof, 'Freedom of Expression and the Right to Information: Implications for Copyright' in C Geiger (ed), Research Handbook on Human Rights and Intellectual Property (Edward Elgar, 2015) 331.

57 C Geiger, 'Fundamental Rights, a Safeguard for the Coherence of Intellectual Property Law?' (2004) 35(3) International Review of Intellectual Property and Competition Law268, 272, stating that 'intellectual property rights constitute islands of exclusivity in an ocean of liberty'. Further on the important implications of the right to freedom of expression for copyright law, see Voorhoof, above n 55; Geiger and Izyumenko, above n 52. For trademarks, M Senftleben, 'Free Signs and Free Use: How to Offer Room for Freedom of Expression within the Trademark System', and for domain names, J D Lipton, 'Free Speech and Other Human Rights in ICANN's New Generic Top Level Domain Process: Debating Top-down versus Bottom-up Protections', both in Research Handbook on Human Rights and Intellectual Property (Edward Elgar, 2015). 
Protocol to the ECHR (guaranteeing the general protection of property) in fact extends, in the absence of a specific Convention clause on IP, to the protection of intellectual property rights. ${ }^{58}$

The inclusion of intellectual property within the protection of property at the constitutional level is important because it expands the social function of property to intellectual property. In fact, the right to property protected by the Convention is inherently limited by its social function. ${ }^{59}$ The first paragraph of article 1 of the First Protocol to the ECHR provides for the possibility of restrictions of the right 'in the public interest', while the second paragraph of the same provision allows the State 'to enforce such laws as it deems necessary to control the use of property in accordance with the general interest ...' ${ }^{60}$

Unlike the ECHR, yet another principal European human rights instrument, the Charter of Fundamental Rights of the European Union (EU Charter), explicitly places intellectual property within its catalogue of fundamental rights. In particular, article 17, dealing with the general right to property under its first paragraph, also contains a second paragraph specifying in a somewhat laconic

58 For the case law of the Court, in accordance with which different intellectual property rights have been attached to the Convention property provision, see, in the field of copyright: Neij and Sunde Kolmisoppi v Sweden (dec) (European Court of Human Rights, no. 40397/12, 19 February 2013); Ashby Donald and Others v France (European Court of Human Rights, no. 36769/08, 10 January 2013); Balan v Moldova (European Court of Human Rights, no. 19247/03, 29 January 2008); Melnychuk v Ukraine (dec) (European Court of Human Rights, no. 28743/03, 5 July 2005, Reports of Judgments and Decisions 2005-IX); Dima v Romania (dec) (European Court of Human Rights, no. 58472/00, 26 May 2005); Aral, Tekin and Aral $v$ Turkey (dec) (European Commission of Human Rights, no. 24563/94, 14 January 1998); A D v the Netherlands (dec) (European Commission of Human Rights, no. 21962/93, 11 January 1994). In the field of trademarks: Paeffgen Gmbh v Germany (dec) (European Court of Human Rights, nos. 25379/04, 21688/05, 21722/05 and 21770/05, 18 September 2007; Anheuser-Busch Inc v Portugal (European Court of Human Rights, Grand Chamber, no. 73049/01, 11 January 2007, Reports of Judgments and Decisions 2007-I). In the field of patent law: Lenzing $A G v$ the United Kingdom (dec) (European Comission of Human Rights, no. 38817/97, 9 September 1998); Smith Kline \& French Lab. Ltd $v$ the Netherlands (dec) (European Comission of Human Rights, no. 12633/87, 4 October 1990, Decisions and Reports 66) 70. For a detailed analysis of the intellectual property case law of the ECHR, see LR Helfer, 'The New Innovation Frontier? Intellectual Property and the European Court of Human Rights' (2008) 49 Harvard International Law Journal 1; DS Welkowitz, 'Privatizing Human Rights? Creating Intellectual Property Rights from Human Rights Principles' (2013) 46 Akron Law Review 675.

59 See, for details on this issue, Geiger, above n 12.

60 Emphasis added. 
way: 'Intellectual property shall be protected' ${ }^{61}$ Even though not devoid of a considerable amount of controversy, this clause needs to be analysed through the prism of the provision within which it is incorporated. Thus, article 17(1) of the EU Charter on the general guarantee of property clearly safeguards the social limits of the right: it reiterates that ' $[\mathrm{t}]$ he use of property may be regulated by law in so far as is necessary for the general interest ${ }^{\prime}{ }^{62}$

This limited nature of the right to property was clearly envisaged by the drafters of both the Charter and the ECHR. As the travaux préparatoires of the First Protocol to the ECHR demonstrate, a newly introduced property paradigm was viewed as being of a 'relative' nature as opposed to the absolute right to own property in a sense it was understood by Roman law. ${ }^{63}$ A similar logic, clearly excluding an 'absolutist' conception of IP, accompanies the preparatory documents of the EU Charter, insofar as the drafters took care to specify that 'the guarantees laid down in paragraph 1 [of article 17] shall apply as appropriate to intellectual property' and that 'the meaning and scope of Article 17 are the same as those of the right guaranteed under Article 1 of the First Protocol to the ECHR' ${ }^{64}$ Article 17(2) of the Charter could then be considered to be nothing more than a simple clarification of article 17(1), with the consequence that there would be absolutely no justification to expand protection on this ground.

61 On this provision, see C Geiger, 'Intellectual Property Shall be Protected!? Article 17(2) of the Charter of Fundamental Rights of the European Union: A Mysterious Provision with an Unclear Scope' (2009) 31(3) European Intellectual Property Review 113; C Geiger, 'Intellectual "Property" after the Treaty of Lisbon, Towards a Different Approach in the New European Legal Order?' (2010) 32(6) European Intellectual Property Review 255. See also J Griffiths and L McDonagh, 'Fundamental Rights and European Intellectual Property Law - The Case of Art 17(2) of the EU Charter' in C Geiger (ed), Constructing European Intellectual Property (Edward Elgar, 2013) EIPIN Series, vol 1, 75.

62 Emphasis added.

63 Council of Europe, Preparatory work on Article 1 of the First Protocol to the European Convention on Human Rights, $\mathrm{CDH}(76) 36$, Strasbourg, 13 August 1976 (see e.g. presentation of Mr de la Vallée-Poussin (Belgium), 12; consider also the statement made by Mr Nally (United Kingdom), 16, that the 'basis of Europe's fight for survival is a struggle for the subordination of private property to the needs of the community').

64 Note from the Praesidium, above n 50, 19-20. 


\title{
It is this 'restrictive' understanding of IP protection that has clearly accompanied the recent case law of the CJEU. ${ }^{65}$ According to the latter:
}

\author{
the protection of the right to intellectual property is indeed \\ enshrined in Article 17(2) of the EU Charter of Fundamental Rights \\ of the European Union. There is, however, nothing whatsoever in the \\ wording of that provision or in the Court's case-law to suggest that \\ that right is inviolable and must for that reason be absolutely protected. ${ }^{66}$
}

65 See e.g. Productores de Música de España (Promusicae) v Telefónica de España SAU ('Promusicae') (C-275/06) [2008] ECJ, Judgment of the Court (Grand Chamber) of 29 January 2008, ECR I-00271, [65]-[68]; LSG-Gesellschaft zur Wahrnehmung von Leistungsschutzrechten GmbH $v$ Tele2 Telecommunication GmbH ('Tele2') (C-557/07) [2009] ECJ, Order of the Court (Eighth Chamber) of 19 February 2009, ECR I-01227, [28], [29]; Bonnier Audio and Others v Perfect Communication Sweden AB (C-461/10) [2012] CJEU, Judgment of the Court (Third Chamber) of 19 April 2012, published in the electronic Reports of Cases, [56]; Painer v Standard VerlagsGmbH and Others ('Painer') (C-145/10) [2011], CJEU, Judgment of the Court (Third Chamber) of 1 December 2011, ECR I-12533, [105], [132]; Scarlet Extended SA v Société belge des auteurs, compositeurs et éditeurs SCRL (SABAM) ('Scarlet Extended') (C-70/10) [2011] CJEU, Judgment of the Court (Third Chamber) of 24 November 2011, ECR I-11959, [53]; Belgische Vereniging van Auteurs, Componisten en Uitgevers CVBA (SABAM) v Netlog NV ('SABAM v Netlog') (C-360/10) [2012], CJEU, Judgment of the Court (Third Chamber) of 16 February 2012, published in the electronic Reports of Cases, [51]; UPC Telekabel Wien GmbH v Constantin Film Verleih GmbH and Wega Filmproduktionsgesellschaft mbH ('UPC Telekabel') (C-314/12) [2014] (CJEU, Judgment of the Court (Fourth Chamber) of 27 March 2014) [46]; and Johan Deckmyn and Vrijheidsfonds VZW $v$ Helena Vandersteen and Others ('Deckmyn') (C-201/13) [2014] (CJEU, Judgment of the Court (Grand Chamber) of 3 September 2014) [26], [27]. On some of these cases, see C Geiger and F Schönherr, 'Limitations to Copyright in the Digital Age' in A Savin and J Trzaskowski (eds), Research Handbook on EU Internet Law (Edward Elgar, 2014), 110, and, from the same authors: 'Defining the Scope of Protection of Copyright in the EU: The Need to Reconsider the Acquis Regarding Limitations and Exceptions' in T Synodinou (ed), Codification of European Copyright Law, Challenges and Perspectives (Kluwer Law International, 2012), 142; J Griffiths, 'Constitutionalising or Harmonising? The Court of Justice, the Right to Property and European Copyright Law' (2013) 38 European Law Review 65; C Geiger, 'The Role of the Court of Justice of the European Union: Harmonizing, Creating and sometimes Disrupting Copyright Law in the European Union' in I Stamatoudi (ed), New Developments in EU and International Copyright Law (Kluwer Law International, 2016) 441; see also the Opinion of the European Copyright Society (ECS), 'Limitations and Exceptions as Key Elements of the Legal Framework for Copyright in the European Union: Opinion on the Judgment of the CJEU in Case C-201/13 Deckmyn' (2015) 37(3) European Intellectual Property Review 129, and J Griffiths et al, 'The European Copyright Society's "Opinion on the Judgment of the CJEU in Case C-201/13- Deckmyn"' (2015) 37(3) European Intellectual Property Review 127.

66 UPC Telekabel (C-314/12) [2014] (CJEU, Judgment of the Court (Fourth Chamber) of 27 March 2014) [61]; SABAM v Netlog, (C-360/10) [2012], CJEU, Judgment of the Court (Third Chamber) of 16 February 2012, published in the electronic Reports of Cases, [41]; Scarlet Extended, (C-70/10) [2011] CJEU, Judgment of the Court (Third Chamber) of 24 November 2011, ECR I-11959, [43] (emphasis added). 
Moreover, to remove any ambiguity, in Luksan $v$ Petrus the CJEU directly referred to article 17(1) of the Charter in the context of IP protection, before discussing article 17(2) - an explicit illustration on the part of the Court that IP clause of the Charter benefits from the more general wording of article $17(1) \cdot{ }^{67}$

The right to property in the Charter and in the ECHR is thus considered as a right having strong social bounds and its scope of protection is therefore limited by nature, ${ }^{68}$ leaving the states a large margin of appreciation to regulate property. ${ }^{69}$ This means that copyright - just like the right to physical property - can be limited in order to safeguard the interests of society at large.

\section{Consequences for the shape and use of copyright as an access right}

\subsection{The need to secure the balance of interests within copyright law: The social contract implies duties for authors and rights for users}

Admitting that intellectual property law has a social purpose and is grounded on human rights obligations should, in principle, lead the legislature to check that copyright rules actually reflect their access aspect and, if not, to correct them. As Professor Schricker aptly noted, if account is taken of the cultural, economic and social consequences of copyright, one might wonder whether the legislature (and the judges interpreting the provisions of copyright law) should not be expected to take account of the general interest in the positive sense: copyright should be conceived of in such a way that it contributes as much as

67 Martin Luksan v Petrus van der Let (C-277/10) [2012] (CJEU, Judgment of the Court (Third Chamber) of 9 February 2012) [68].

68 See in this sense, C Calliess, 'The Fundamental Right to Property' in D Ehlers (ed), European Fundamental Rights and Freedoms (De Gruyter, 2007) 456, stating that the social function 'serves as a justification for and limitation of the restrictions imposed on property utilisation'.

69 For example, in the Smith Kline case (Smith Kline \& French Lab Ltd $v$ the Netherlands, (European Commission of Human Rights, no. 12633/87, 4 October 1990, Decisions and Reports 66)), the European Commission of Human Rights stated that the grant under Dutch law of a compulsory licence for a patented drug was not a violation of article 1 of the First Protocol. It considered that the compulsory licence was lawful and pursued the legitimate aim of encouraging technological and economic development. 
possible to the development of intellectual, cultural and economic progress. ${ }^{70}$ This would require a legislator to first justify convincingly the grant of intellectual property rights (which seems difficult where the rule is the pure result of pressure from certain interest groups), and then to exercise subsequently a sort of 'self-monitoring'. In this sense, the social function with its integral access aspect could imply a duty to demonstrate why legislation is passed and what results are to be obtained, by means of reliable data and impact studies that will make it possible to measure the probable consequences of the legislative activity. ${ }^{71}$ This would have a very important consequence, since the legislator would have an obligation to justify any extension of intellectual property law. Moreover, this could imply that the legislator periodically evaluates the results of past copyright legislations and verifies that they have led to the desired results, with the logical consequence of having to modify them when this is found not to be the case. ${ }^{72}$ A good example is the steady increase over time of the term of protection of copyright and neighbouring rights, which has regularly caused heated debates among scholars and copyright experts,

70 G Schricker, 'Introduction' in G Schricker (ed), Urheberrecht Kommentar (Beck, $2^{\text {nd }}$ ed, 1999) 7.

71 See in this sense, in the context of the EU, C Geiger, 'The Construction of Intellectual Property in the European Union: Searching for Coherence' in C Geiger (ed), Constructing European Intellectual Property: Achievements and New Perspectives (Edward Elgar, 2013) EIPIN Series, vol 1, 5, advocating that future initiatives by the European legislature need to be based more frequently on serious (and above all independent) economic data and on impact studies that will make it possible to measure the probable consequences of the legislative activity. See also the report of Professor I Hargreaves, 'Digital Opportunity, A Review of Intellectual Property and Growth', May 2011, 1, inviting the legislature 'to ensure that in the future, policy on Intellectual Property issues is constructed on the basis of evidence, rather than weight of lobbying'. More generally on the importance of evidence-based policies in copyright law, see recently J Poort, Empirical Evidence for Policy in Telecommunication, Copyright and Broadcasting (Amsterdam University Press, 2015) 9: 'Increasingly, politicians, judges and stake holders require economic analysis and economic evidence to make informed decisions about new policy measures, to make optimal decisions within the legal boundaries and to fathom the proposed consequences of proposed legal interventions. Without empirical evidence they may simply assume the effects of a policy measure as an article of faith' (emphasis added).

72 At present in the EU, it is true that the Commission sometimes undertakes evaluations of past directive. However, an unsatisfying result of past legislation hardly leads to any action. A good example has been the negative evaluation of the legal protection for databases, implemented in the EU through a very complicated legal instrument, which according to the Commission's own admission did not had the expected success (see the evaluation of Directive 96/9/EC on the legal protection of databases published by the European Commission on 12 December 2005. On this text, see A Kur et al, 'First Evaluation of Directive 96/9/EC on the Legal Protection of Databases - Comment by the Max Planck Institute for Intellectual Property, Competition and Tax Law' (2006) International Review of Intellectual Property and Competition Law, 551). Despite the evaluation, the legal instrument has not been modified or abolished. 
criticising this extension as being detrimental to the public domain and leading rather to rent-seeking than to an increase of creation of new works. ${ }^{73}$

The question then arises: how to oblige the legislature to respect copyright as an access right? This could be the case if an access aspect of intellectual property is established at a supra-legislative level. The problem is that in the European Union and some of its member states, unlike in the United States, there is no constitutional clause regulating the activity of the legislature when it comes to passing intellectual property legislation. However, as emphasised above, intellectual property has been raised to the supra-legislative level by attaching it to the constitutional protection of the right to property, which may be subjected to restrictions that are justified by the general interest. In this spirit, the German Constitutional Court has laid down very clearly in the context of copyright that while the protection of property rights:

implies that the economic benefits of the work are in principle owed to the author, the constitutional protection of property rights does not extend to all these benefits. It is for the legislature to set out the contours of copyright by imposing appropriate criteria that take account of the nature and social function of copyright and to ensure that the author participates in the exploitation of the work fairly. ${ }^{74}$

73 See e.g. R Pollock, 'Optimal Copyright Over Time: Technological Change and the Stock of Works' (2007) vol 4, no 2, Review of Economic Research on Copyright Issues, 51; C Buccafusco and PJ Heald, 'Do Bad Things Happen When Works Enter the Public Domain?: Empirical Tests of Copyright Term Extension' (2013) vol 21, issue 1, Berkeley Technology Law Journal, 1. A recent example in the EU for a strongly criticised measure in this regard has been the Directive extending the term of neighbouring rights from 50 to 70 years (Directive 2011/77/EU of the European Parliament and of the Council of 27 September 2011 amending Directive 2006/116/EC on the term of protection of copyright and certain related rights [2011] OJ L 265, 1-5), which was based on no independent economic study and has been massively rejected by the majority of European academics: 'Creativity stifled? A Joint Academic Statement on the Proposed Copyright Term Extension for Sound Recordings' (2008) European Intellectual Property Review 341; C Geiger, J Passa and M Vivant, 'La proposition de directive sur l'extension de la durée de certains droits voisins: Une remise en cause injustifiée du domaine public' [2009] No 31, Propriété intellectuelle, 146; C Geiger, 'The Extension of the Term of Copyright and Certain Neighbouring Rights - A Never Ending Story?' (2009) International Review of Intellectual Property and Competition Law, 78.

74 German Constitutional Court, 'Schoolbook' decision, 7 July 1971 (1972) Gewerblicher Rechtsschutz und Urheberrecht, 481 (emphasis added); W Rumphorst, Comment, (1972) International Review of Intellectual Property and Competition Law, 394. 
The legislature is thus subjected to an obligation of moderation. This obligation of balance is accentuated by the fact that the legislature is required, when laying down the contours of the right, to respect other fundamental rights of equal value; ${ }^{75}$ it is for this reason, moreover, that all legislation on intellectual property rights imposes a certain number of limitations and exceptions on the exclusive right. To a large extent, attaching intellectual property rights to fundamental rights thus guarantees respect for the social function of these rights. ${ }^{76}$ In practical terms, it can even be asked if the obligation to protect competing fundamental rights and values when implementing new intellectual property legislation should not oblige the legislator also to implement legal duties for right holders. ${ }^{77}$ Philosophically speaking, this would clearly be in line with the idea of the social contract underlying the social function, which implies counterparts. As one scholar has interestingly stated, 'the grant of a right in the intellectual property may itself be derivative of a duty to others; that is, when the intellectual property owner acquires a legal intellectual property right, a duty to the public is simultaneously imposed on the intellectual property owner' ${ }^{78}$

Such obligations imposed on right holders could for example result in a duty to disseminate as widely as possible protected creations and to exploit them. This could result in a prohibition to prevent the dissemination of any protected creation: for example, by securing access to orphan, out of print works, forbidding the use of contracts or TPMs (technological protection measures) that are blocking access through exceptions and limitations, and other analogous obligations. ${ }^{79}$

75 C Geiger, 'Reconceptualizing the Constitutional Dimension of Intellectual Property' in $\mathrm{P}$ Torremans (ed), Intellectual Property and Human Rights (Kluwer Law International, $3^{\text {rd }}$ ed, 2015), 115; C Geiger, 'Copyright's Fundamental Rights Dimension at EU Level' in E Derclaye (ed), Research Handbook on the Future of EU Copyright (Edward Elgar, 2009), 27; Geiger, 'Intellectual "Property" after the Treaty of Lisbon', above n 60; C Geiger, 'Fundamental Rights as Common Principles of European (and International) Intellectual Property Law' in A Ohly (ed), Common Principles of European Intellectual Property Law (Mohr Siebeck, 2012), 223.

76 C Geiger, 'Fundamental Rights, a Safeguard for the Coherence of Intellectual Property Law?', above n 56 .

77 For details on the legal consequences of the 'constitutionalisation' of intellectual property for legislators, see Geiger, above n 39, 397 et seq.

78 EF Judge, 'Intellectual Property Law as an Internal Limit on Intellectual Property Rights and Autonomous Source of Liability for Intellectual Property Owners' (2007) 27(4) Bulletin of Science, Technology \& Society, 311. On the idea of duties of authors in the field of copyright law, see C Colin, 'The Author's Duty' (2010) (224) Revue Internationale du Droit d'Auteur, 160. 79 For further proposals resulting from the obligation to secure access, see C Geiger, 'The Future of Copyright in Europe: Striking a Fair Balance between Protection and Access to Information' 
The right holders' duties would also envisage allowance of a public discourse about a certain creation through parody, quotations, creative reuse and alike. As can be seen, some of these duties clearly result from fundamental rights such as freedom of expression, freedom of information, artistic freedom or freedom to conduct a business, and the positive obligation of the State to protect those rights could imply that mechanisms are inserted in intellectual property law to secure these values.

One such mechanism would be to grant users' rights which could be enforced in courts. ${ }^{80}$ Limitations to intellectual property rights, which are based on fundamental rights and thereby represent basic democratic values within IP law, could be elevated to rights of the users (and not mere interests to be taken into account), which are of equal value as the exclusive right. ${ }^{81}$ The consequence of this is that they should be considered mandatory (which means the user's exercise of statutory limitations cannot be restricted by contract $)^{82}$ and should prevail over technical measures. The national legislatures could introduce into their acts a prohibition of technical devices that

(2010) Intellectual Property Quarterly, 1. One of the duties of right holders could be to guarantee that access is granted under fair conditions (pricing issue) and that the business models are adapted to the needs of consumers (easy to use, diversity of content, usable on a variety of devices etc.). In fact, granting access under unfair conditions or at too high a price results often in hindering access for a majority of people. Libraries and archives have a particular role to play here, and there could be a duty to make the work available also through these channels.

80 Favouring the granting of positive rights to users, see also e.g. R Burell and A Coleman, Copyright Exceptions: The Digital Impact (Cambridge University Press, 2005) 279; T Riis and J Schovsbo, 'User's Rights, Reconstructing Copyright Policy on Utilitarian Grounds' (2007) European Intellectual Property Review 1; Geiger, above n 19, 371 et seq. In the context of technical measures, see A Ottolia, 'Preserving Users' Rights in DRM: Dealing with "Judicial Particularism" in the Information Society' (2004) 35 International Review of Intellectual Property and Competition Law, 491 .

81 See for a more detailed analysis, C Geiger, 'Promoting Creativity through Copyright Limitations: Reflections on Concept of Exclusivity in Copyright Law' (2010) 12(3) Vanderbilt Journal of Entertainment \& Technology Law 515. See also CCH Canadian Ltd $v$ Law Society of Upper Canada [2004] 1 SCR 339.

82 The Belgian law states this imperative character of copyright exceptions explicitly (see article 23bis of the Belgian Act of 30 June 1994, inserted by an Act of 31 August 1998, which implemented the Database Directive in Belgian law). The mandatory character of the exceptions was maintained in the new Belgian Act of 22 May 2005 (M.B., 27 May 2005, 24997; on this Act, see M-C Janssens, 'Implementation of the 2001 Copyright Directive in Belgium' (2006) 37 International Review of Intellectual Property and Competition Law 50), except for the works made available to the public on agreed contractual terms (article 7). In France, the imperative nature of copyright exceptions could be deduced from the wording of article L 122-5 of the Intellectual Property Code, as it specifies that 'the author cannot prohibit' the uses there stated. The Paris District Court in its decision of 10 January 2006 (2006) 13 Revue Lamy Droit De L'immatériel, 24, even held explicitly that the private copy exception was 'd'ordre public', meaning mandatory, 
prevent a use privileged by law, or at least grant the user judicial means to 'enforce' his exceptions (this would lead to the creation of a 'subjective right' to the exception). In the European context, such action could even be deduced from the InfoSoc Directive. ${ }^{83}$ According to article 6(4) of the Directive, member states shall take 'appropriate measures' to ensure the functioning of certain limitations when technical measures are implemented. However, the Directive does not specify what these measures could consist of. Arguably, it would be contrary to the states' obligations under article 15 ICESCR, article 10 ECHR and to the social function of copyright if it is not assured that the beneficiaries of exceptions listed in article 6(4) are able to benefit from them.

Importantly, the idea of users' rights as enforceable rights of equal value appears to have found its way into the recent practice of the CJEU. ${ }^{84}$ In particular, in its decision in UPC Telekabel from March 2014, the Court clearly adopted the language of users' rights as a counterbalance to the disproportionally extensive enforcement of copyright. ${ }^{85}$ The Court, by obliging the national authorities (albeit under the limited range of circumstances) to avail the users of the procedural opportunity to challenge copyright enforcement measures

and therefore that a technical measure should not hinder the making of a copy of a CD. But the French Supreme Court has since then taken a different position (28 February 2006 (2006) Recueil Dalloz 784).

83 Directive 2001/29/EC of the European Parliament and of the Council of 22 May 2001 on the harmonisation of certain aspects of copyright and related rights in the information society (InfoSoc) [2001] OJ L 167, 10.

84 See Technische Universität Darmstadt v Eugen Ulmer KG ('Ulmer') (C-117/13) [2014] (CJEU, Judgment of the Court (Fourth Chamber) of 11 September 2014) [43]; CJEU, Case C-201/13, Deckmyn, (C-201/13) [2014] (CJEU, Judgment of the Court (Grand Chamber) of 3 September 2014) [26]; UPC Telekabel, (C-314/12) [2014] (CJEU, Judgment of the Court (Fourth Chamber) of 27 March 2014) [57]; Padawan SL $v$ Sociedad General de Autores y Editores de España (SGAE) ('Padawan') (C-467/08) [2010], CJEU, Judgment of the Court (Third Chamber) of 21 October 2010, ECR I-10055, [43]; Painer, (C-145/10) [2011], CJEU, Judgment of the Court (Third Chamber) of 1 December 2011, ECR I-12533, [132]. For the further discussion of these cases, see ECS, above n 64.

85 UPC Telekabel (C-314/12) [2014] (CJEU, Judgment of the Court (Fourth Chamber) of 27 March 2014). For a comment see C Geiger and E Izyumenko, 'The Role of Human Rights in Copyright Enforcement Online: Elaborating a Legal Framework for Website Blocking' (2016) 32 American University International Law Review 43. 
before the courts, ${ }^{86}$ accepts the idea that fundamental right (in the instant case - freedom of expression) may be invoked as not a mere defence but as a right on which an action in the main case is based. Since UPC Telekabel, the idea of users' rights has already reoccurred in Ulmer from September 2014. Notably, the CJEU referred in that case to the 'ancillary right' of users to digitise works contained in publicly accessible libraries' collections ${ }^{87}$ In the Court's opinion, such a right of communication of works enjoyed by establishments such as publicly accessible libraries would stem from the exception in article 5(3)(n) InfoSoc for the purpose of research and private study. In the light of this recent case law of the CJEU, it can be argued that the Court moves towards understanding human rights as an integral part of the European copyright order in full recognition of the above-examined social function of IP law and its underlying human rights rationales.

On the other side of the Atlantic, an analogously liberal stance has been taken by the Supreme Court of Canada, which, since its groundbreaking Théberge ${ }^{88}$ and $\mathrm{CCH}^{89}$ decisions, was increasingly emphasising 'a move away from an earlier, author-centric view' towards 'promoting the public interest' and the 'users' rights [as] an essential part of furthering the public interest objectives of the Copyright Act' $^{90}$ Interestingly, the Court explicitly referred in these cases to the 'proper balance between protection and access' as an ultimate goal of any copyright law regulation. As we have seen, the same dual rationale underlines the protection of creators under article 27 UDHR and article 15 ICESCR - provisions intrinsically integrating the access and protection aspects of copyright.

86 UPC Telekabel, (C-314/12) [2014] (CJEU, Judgment of the Court (Fourth Chamber) of 27 March 2014) [57]: '[I]n order to prevent the fundamental rights recognised by EU law from precluding the adoption of an injunction such as that at issue in the main proceedings, the national procedural rules must provide a possibility for internet users to assert their rights before the court once the implementing measures taken by the internet service provider are known' (emphasis added).

87 Ulmer, (C-117/13) [2014] (CJEU, Judgment of the Court (Fourth Chamber) of 11 September 2014) [43].

88 Théberge $v$ Galerie d'Art du Petit Champlain Inc, [2002] 2 SCR 336.

89 CCH Canadian Ltd $v$ Law Society of Upper Canada, [2004] I SCR 339.

90 SOCAN $v$ Bell Canada, [2012] 2 SCR 326, [9]-[11]. See also Alberta (Minister of Education) $v$ Canadian Copyright Licensing Agency (Access Copyright), [2012] 2 SCR 345. For an excellent analysis of the Canadian Supreme Court's jurisprudence on users' rights, see D Vaver, 'User Rights' (2013) 25 Intellectual Property Journal 105. See also P Chapdelaine, 'The Ambiguous Nature of Copyright Users' Rights' (2013) 26 Intellectual Property Journal 1. 
In short, it can be stated that the legislator should secure that the human rights implementation within the intellectual property regimes is safeguarded from private ordering. This implies for example that at least the exceptions and limitations that are justified by human rights rationales are declared mandatory ${ }^{91}$ and that mechanisms are implemented to secure their effectiveness, especially in the digital environment (where they are endangered by technical protection measures and online contracts). ${ }^{92}$

\subsection{The revision of the balance of interests within copyright law: Towards a new paradigm?}

\subsubsection{A more restrictive understanding of the conditions of protection}

If one considers intellectual property rights as exceptions to a major principle of the freedom of use, ${ }^{93}$ then this implies also some changes in positive law. Very simply, this could imply that the exclusive rights would have to be conceived restrictively and the limitations broadly, at least in a flexible manner. This could for example be achieved by changing the perspective and introducing a sort of three-step test to determine access to protection.

\subsubsection{Towards a three-step test to gain access to copyright protection?}

The idea of having a 'test' to qualify for protection is commonly accepted in countries such as the UK, where the judges for a long time used to appeal to the 'skill-and-labour-test' to decide whether a creation can be protected or not. ${ }^{94}$

91 Not all the exceptions and limitations have the same justification and importance with regard to securing access. The limitations that necessitate particular attention include exceptions for libraries and archives, for teaching and research purposes, for news reports, for press reviews, for quotations and parodies and, more incidentally, exception for people with disabilities, as well as private copying when it allows access to information and is not covered by one of the exceptions already mentioned.

92 See C Geiger, "The Answer to the Machine should not be the Machine, Safeguarding the Private Copy Exception in the Digital Environment' (2008) European Intellectual Property Review 121.

93 See Geiger, 'Fundamental Rights, a Safeguard for the Coherence of Intellectual Property Law?', above n 56.

94 For just a few examples, see High Court of Justice, Chancery Division, 7 April 2006, 2006 EWHC 719; and Court of Appeal, Civil Division, 28 March 2007, WC2A 2LL. 
Therefore, it would be interesting to elaborate a certain number of criteria that an expression would need to satisfy in order to enjoy protection. For this, the American conception of fair use or the threestep test, which sets criteria for exempted use, could serve as a model, except that such a test would not circumscribe the limitations but provide for the conditions of access to protection.

Now, what would be these criteria? First, in order to have a uniform approach (between continental and common law), the criterion of creativity is to be preferred to 'originality', usually defined as the 'print of the author's personality'. The second is too difficult to determine and involves the risk of arbitrariness. Moreover, referring to the function of law as an instrument to promote creativity, property should only be granted if there is any creative contribution or collective enrichment. Thus, henceforth, it should be the degree of creativity that separates protected from unprotected forms.

In this context, Professor Mireille Buydens of the University of Brussels has suggested a very interesting distinction between creation protected by copyright law and 'quasi-creation', which would benefit from a different type of protection. According to her, the freedom of which the creator disposes constitutes the distinctive criterion. ${ }^{95}$ Consequently, in order to decide whether a work may enjoy copyright protection or protection by some sui generis right (meaning a kind of investment protection), the court will assess whether the originator has been essentially free during the process of creation or if, on the contrary, his freedom has been accessory because he had to observe all sorts of necessities. For example, the creative freedom of a designer who creates a furniture design is most often limited by functional necessities (a chair must have several characteristic features), by necessities due to the method of production (series production, costs) and by public taste (trends of style). ${ }^{96}$

95 M Buydens, 'La protection de la quasi-création' (Larcier, 1989), 252. See also M Buydens, 'The Conditions and Scope of Copyright Protection' in R M Hilty and C Geiger (eds), 'The Balance of Interests within Copyright Law' (2006) Proceedings of the conference organised in Berlin by the Max Planck Institute for Intellectual Property, 4-6 November 2004, Munich, available online at $<$ www.intellecprop.mpg.de $>$.

96 Buydens, 'La protection de la quasi-création', above n 94, 276. The criterion of freedom of the designer is used to determine the scope of protection in the field of design law (see article 9(2) of Directive 98/71/EC of 13 October 1998 on the legal protection of designs, OJ EC L 289 of 28 October 1998, 28: 'In assessing the scope of protection, the degree of freedom of the designer in developing his design shall be taken into consideration'). 
The distinctive criterion concerning creation and quasi-creation is whether the freedom of the creator has been accessory or principal. If necessities concerning function, type, current style and methods of production are predominant, the work will be excluded from copyright protection. Concerning the protection of all the creations that are consequently excluded, Mireille Buydens suggests creating a specific system of quasi-creation that is meant to complement existing legal instruments (design law in particular). Evidently, there is a need to envisage new solutions or to improve existing instruments. This is not the place to specify details, but it shows that it is possible to find more objective criteria for deciding whether a form is protected or not by copyright. Furthermore, the judge could also take into consideration the consequences that copyright protection might have on creations in the future as well as the impact of the right on the availability of information and the common interest. This would mean that courts should also take into account some fundamental-rights rationales when deciding whether the work enjoys protection or not. ${ }^{97}$ In fact, public interest objectives such as competition law and certain fundamental rights, generally a justification for exempting a certain use, could already be taken into consideration at the protection level. Hence, certain forms could be excluded from protection because of their importance to society, following the example of article 2(4) of the Berne Convention of $1886 .{ }^{98}$ This would result in giving the public domain a positive definition. ${ }^{99}$ Let us take, for example, the case of a photograph capturing the assassination of a famous person, or a letter from an important politician who has been involved in a corruption scandal. It would be possible to take into account the freedom of expression and the public's right to information (article 10

\footnotetext{
97 See in this sense Geiger, above n 39.

98 Berne Convention for the Protection of Literary and Artistic Works, opened for signature 9 September 1886 (amended in 1914, 1928, 1948, 1967, 1971, and 1979) 25 UST 1341, 828 UNTS 221, entered into force 5 December 1887 ('Berne Convention'), article 2(4): 'It shall be a matter for legislation in the countries of the Union to determine the protection to be granted to official texts of a legislative, administrative and legal nature, and to official translation of such texts'. 99 The notion and the content of the public domain are still not really clarified in legal literature. On this issue, see e.g. J Litman, 'The Public Domain' (1990) 39 Emory Law Journal 965; J Boyle (ed), 'The Public Domain' (2003) 66(1)-(2) Law \& Contemporary Problems; PB Hugenholtz and L Guibault (eds), The Public Domain of Information (Kluwer Law International, 2006); S Dusollier and V-L Benabou, 'Draw Me a Public Domain' in P Torremans (ed), Copyright Law: A Handbook of Contemporary Research (Edward Elgar, 2007) 161. Unlike in the environmental sector, the preservation of informational resources has not been legally secured so far.
} 
ECHR) already when deciding whether the expression is protected or not, and refuse to grant copyright protection due to important public interest motives.

Incidentally, certain decisions seem to indicate a change of approach in this direction. For example, in Germany the Düsseldorf District Court in its decision of 25 April $2007^{100}$ refused copyright protection to a simple presentation of news information in default of individuality. Likewise, in the Netherlands, the Court of Appeal of Amsterdam ${ }^{101}$ refused to protect a recorded conversation of a person reprinted in a book on the grounds that the person answering the questions did not have the intention to create a work. ${ }^{102}$ Even if the court did not refer to article 10 ECHR, it seems that the court implicitly balanced the interest of the right holders with those of the public to be informed about the conversation already at the protection level and let the freedom of information prevail. In a similar vein, when the French courts exclude in a very radical way perfume from copyright protection, this is certainly likewise part of an effort to restrain the field of protection. ${ }^{103}$

100 Düsseldorf District Court, Case No 120 194/06, 25 April 2007.

101 The Amsterdam Court of Appeal, Endstra's Sons v Middelburg, Vugts and Nieuw Amsterdam, 8 February 2007, (2007) (4) AMI.

102 Note, however, that this ruling was subsequently referred back to appeal by the Dutch Supreme Court, concluding that copyright protection without an intention to create was not impossible by definition. The Supreme Court stated that though it is true that there must be human labour and therefore creative choices, it is however not important whether the author has intentionally wanted to create a work and has intentionally wanted to make particular original choices (Dutch Supreme Court, Endstra's Sons v Middelburg, Vugts and Nieuw Amsterdam, Case No C07/131HR, 30 May 2008. For a comment, see B Beuving, 'Endstra's Final Work? Dutch Copyright: Scope of Protection Remains Very Wide' (February 2009) Bird \& Bird Copyright Update 24, 26). For the second (and final) appeal decision on this case, see The Amsterdam Court of Appeal, Endstra's Sons v Middelburg, Vugts and Nieuw Amsterdam, 16 July 2013.

103 See French Supreme Court, $1^{\text {st }}$ Civil Division, 13 June 2006, (2006) 37 International Review of Intellectual Property and Competition Law 988: 'The fragrance of a perfume, which results from the simple implementation of know-how, does not constitute the creation of a form of expression capable of benefiting from the protection provided by copyright for works of the mind within the meaning of Arts. L. 112-1 and L. 112-2 of the Intellectual Property Code'. However, since then the lower courts have refused to follow the approach of the Supreme Court and continued to accept copyright protection: District Court of Bobigny, 28 November 2006, Communication Commerce électronique, at 13, comment by C Caron; and Paris Court of Appeal, $4^{\text {th }}$ chamber A (February 2007) 14 February 2007, (2008) 39 International Review of Intellectual Property and Competition Law 113. 


\subsubsection{Formulating a three-step test to access copyright protection}

The above-examined considerations would lead to the following general clause: 'Only expressions that are the result of a creational process in which the freedom of the creator has been superior to imposed necessities and which neither interfere unduly with future creation nor cause unjustified harm to legitimate public interests such as cultural participation may enjoy copyright protection'. Thus, access to copyright protection would be determined by a proper 'three-step test', serving as a guiding rule to the judges. Of course, the first criterion would be preponderate, but the two further criteria would serve as correctives, particularly by excluding a form from protection if there is no sufficient dissemination enabling cultural participation, ${ }^{104}$ or, if granted, the protection would lead to a strong risk of predominantly negative consequences for innovation. The last might be the case, for example, if a form is to be considered an essential facility, that is, that its use constitutes the condition to accede to a certain market. Of course, all these criteria can also be taken into account at the level of copyright limitations. The objective of the second step, for example, could be reached by the implementation of an exception for creative use. ${ }^{105}$ However, it might seem unsatisfying to grant protection where the consequence on innovation and creativity could be harmful and then take it back by a complicated exemption mechanism. If the function of copyright law with its inalienable access aspect is taken seriously, protection that could be detrimental to future creativity should not be granted in the first place. Of course, even though the judges could already use such criteria when deciding on the eligibility of a work for copyright protection, a legal implementation of this new three-step test would be desirable in order to have more transparency for the economic players.

It worth noting that by following this procedure, the French theory of the 'unite de l'art' would probably have to be abandoned. This theory, according to which copyright protection is not excluded because

104 On the duty of right holders to disseminate a copyrighted work as a counterpart of copyright protection, see earlier discussion in this chapter, under subheading II A: 'The need to secure the balance of interests within copyright law: The social contract implies duties for authors and rights for users.'

105 On the implementation of such an exception to foster creativity, see C Geiger, 'Copyright and the Freedom to Create, A Fragile Balance' (2007) 38 International Review of Intellectual Property and Competition Law 707. 
of the utility of a work, would lose all its interest. In fact, either the creator has enjoyed sufficient freedom during the creation process and will thus enjoy copyright protection, or the creative factor has only been accessory because of numerous necessities, in which case he will have access to another system of protection (e.g. design law). Consequently, one would need to distinguish whether a utility work is predominantly creative or functional. It is true that there is a certain risk that certain peripheral creations might be 'declassed' to functional objects. This, however, is the price to pay in order to 'purify' copyright law from certain forms and to guarantee a certain availability of information (which represents nothing more than ideas 'put into form'). It must also be specified that this does not mean that these works will go unprotected. They will merely not be protected by such a strong and enduring protection as copyright, but by other existing protection mechanisms (or mechanisms that would have to be created). ${ }^{106}$

\subsubsection{An extensive/flexible understanding of copyright limitations}

As demonstrated above, in view of the approach that free use (freedom of expression, freedom of science and arts) represents the principle, and exclusive rights the exception, limitations to exclusivity cannot be considered as 'exceptions' to the principle of exclusivity. At the end, the demand for a more extensive and rigorous protection, ${ }^{107}$ as well as the postulate of a narrow interpretation of copyright limitations, represents a purely political statement. In this context, what would matter is only whether copyright regulation achieves the desired purpose, not what legal technique (exclusive right or limitation) is used. In fact, 'exceptions' ${ }^{108}$ are no more than simple tools for the

106 Advocating the creation of a special investment-protection mechanism, see RM Hilty, 'The Law Against Unfair Competition and its Interfaces' in RM Hilty and F Henning-Bodewig (eds), Law Against Unfair Competition, Towards a New Paradigm in Europe (Springer, 2007), 1.

107 See in this sense, in the context of Europe, e.g. recital 11 to Directive 2001/29/EC of the European Parliament and of the Council of 22 May 2001 on the harmonisation of certain aspects of copyright and related rights in the information society (InfoSoc) [2001] OJ L 167,; recital 16 to Directive 2006/115/EC of the European Parliament and of the Council of 12 December 2006 on rental right and lending right and on certain rights related to copyright in the field of intellectual property (codified version), OJ No L 376 of 27 December 2006, 28. See also the Commission of the European Communities, Green Paper: Copyright in the Knowledge Economy (COM, 2008, 466 final), 4.

108 As limited to our specified interpretation of it, the term 'limitation' appears more appropriate. On the distinction between the terms 'exception' and 'limitation', see C Geiger, 'Promoting Creativity through Copyright Limitations: Reflections on Concept of Exclusivity in Copyright 
legislators to delimit the scope of the right, in order to maintain the balance of right holders' and users' rights. ${ }^{109}$ Hence, they should be interpreted in accordance with their underlying justification. Starting out from the assumption that copyright serves the interest of society by encouraging creation of new works, it is necessary to permit sufficient free space for creativity.

Furthermore, even in economic terms, the value of limitations can be measured in various forms, typically showing the benefits of such a system. ${ }^{110}$ There are, in fact, numerous businesses that use 'free' material - meaning material where uses are permitted by a limitation (so-called 'added value services') - to generate income and economic growth. ${ }^{11}$ Even if the limitation provides for the payment of remuneration, the absence of costs related to finding the right holder and the negotiation of a license (not to mention, in case of problems, the costs related to litigation), also has a measurable value, and therefore facilitates the creative reuses of existing works. ${ }^{112}$

In some cases, changes in technical or social circumstances might yet require extensive interpretation and even the creation of new exceptions by analogy (i.e. without legal basis). ${ }^{113}$ Otherwise,

Law' (2010) 12(3) Vanderbilt Journal of Entertainment \& Technology Law 515, 518 et seq.

109 See in particular PB Hugenholtz, 'Adapting Copyright to the Information Superhighway' in PB Hugenholtz (ed), The Future of Copyright in a Digital Environment (Kluwer, 1996), 94; M Vivant, 'La limitation ou "reduction" des exceptions au droit d'auteur par contrats ou mesures techniques de protection. De possibles contrepoids?' (General Report presented at the ALAI Study Days, Barcelona, 19-20 June 2006); C Geiger, 'Der urheberrechtliche Interessensausgleich in der Informationsgesellschaft' (2004) Gewerblicher Rechtsschutz und Urheberrecht, Internationaler Teil 815.

110 See L Gibbons, 'Valuing Fair Use' (Paper presented at the Conference on Innovation and Communication Law, University of Turku, Finland, 17 July 2008).

$111 \mathrm{~T}$ Rogers and A Szamosszegi, Fair Use in the U.S. Economy: Economic Contribution of Industries Relying on Fair Use (Computer \& Communications Industry Association, 2011); L Gibbons and XL Wang, 'Striking the Rights Balance Among Private Incentives and Public Fair Uses in the United States and China' (2008) 7 John Marshall Review of Intellectual Property Law 488, 494; B Gibert, 'The 2015 Intellectual Property and Economic Growth Index: Measuring the Impact of Exceptions and Limitations in Copyright on Growth, Jobs and Prosperity' (The Lisbon Council, 2015); K Erickson et al, 'Copyright and the Value of the Public Domain: An Empirical Assessment', Study for the UK Intellectual Property Office, January 2015.

112 See further C Geiger, 'Statutory Licenses as an Enabler of Creative Uses' in RM Hilty and K-C Liu (eds), Remuneration of Copyright Owners: Regulatory Challenges of New Business Models (Springer, forthcoming 2017).

113 See in this sense, e.g. M Buydens and S Dusollier, 'Les exceptions au droit d'auteur: Évolutions dangereuses' (September 2001) Communication Commerce électronique, 11; C Geiger, 'Creating Copyright Limitations Without Legal Basis: The 'Buren' Decision, a Liberation?' (2005) 36 International Review of Intellectual Property and Competition Law, 842; J-C Galloux, 
'freezing' the status quo of exceptions would prevent any adaptability of the system. It is necessary to bear in mind that the system of exceptions has not changed much in most European countries, and, where it has, such changes have never lived up to the expectations raised by a real adaptation of copyright law to the information society'. Many authors have pointed out that the 2001 Directive on the harmonisation of copyright in the information society failed in this matter ${ }^{114}$ by only providing a list of facultative exceptions, so that the European legislature did not oblige national legislatures to modernise their copyright laws. ${ }^{115}$ Therefore, there are justifiable doubts that current legislations are still 'up to date'. By this token, courts are now tending towards renouncing the principle of restrictive interpretation by sometimes permitting a reasoning by analogy ${ }^{116}$ or creating exceptions beyond legal statutes. By way of example, even in France - a country that is known to have a very restrictive understanding of copyright limitations - judges have created an exception of accessory reproduction ${ }^{117}$ without a statutory basis.

It is true that, unlike those countries that have the exception of fair use at their disposal, the continental system does not provide the judge with any suitable instrument concerning limitations. The threestep test incorporated in the InfoSoc Directive, however, might enable judges in the future to apply exceptions in a more flexible

\footnotetext{
'Les exceptions et limitations au droit d'auteur: Exception française ou paradoxe français?' in RM Hilty and C Geiger (eds), Impulse für eine europäische Harmonisierung des Urheberrechts (Springer, 2007), 329 et seq. However, it has to be admitted that there are numerous voices urging in the opposite direction, too.

114 See e.g. RM Hilty and M Vivant, 'La transposition de la directive sur le droit d'auteur et les droits voisins dans la société de l'information en Allemagne et en France, Analyse critique et prospective' in RM Hilty and C Geiger (eds), Impulse für eine europäische Harmonisierung des Urheberrechts (Springer, 2007) 51, 71.

115 See in this sense the study conducted by Instituut voor Informatierecht (IViR) of the University of Amsterdam, 'The Recasting of Copyright and Related Rights for the Knowledge Economy', November $2006<$ www.ivir.nl >, 75, which recommends that certain limitations should be declared obligatory in order to assure an effective harmonisation.

116 See for example in this sense the decision by the Supreme Court of the Netherlands of 20 October 1995 in the proceeding Dior v Evora (1996 NJ 682), where the Court estimates that it is not forbidden to judge by analogy in a situation the legislature could not have foreseen.

117 French Supreme Court, $1^{\text {st }}$ Civil Division, 15 March 2005, (2005) 36 International Review of Industrial \& Copyright 869. See on this decision also Geiger, 'Creating Copyright Limitations Without Legal Basis', above n 112. See also Bordeaux Court of Appeal, 13 June 2006, (2007) (238) Légipresse 5, comment by A Maffre-Baugé, on the reproduction of an image for a reportage about the audience of a famous court case.
} 
way. ${ }^{118}$ According to article 5(5) of the Directive, 'exceptions and limitations ... shall only be applied in certain special cases which do not conflict with a normal exploitation of the work or other subjectmatter and do not unreasonably prejudice the legitimate interests of the rightholder ${ }^{\prime}{ }^{119}$ The judge - being the person who generally applies the exception - will henceforth be able to use this legal instrument in order to adapt exceptions to circumstances that have not been provided for by copyright law. ${ }^{120}$ In fact, this flexibility need not lead to a reduction of the exceptions. With a certain free hand granted generally to the judge, this freedom of action should logically not only be used to restrict but also to extend. ${ }^{121}$ It is true that this fact might be slightly detrimental to legal certainty. Yet this is the price to be paid in order to achieve a refined application of exceptions (in both senses) and, thus, an adaptation of the system to new circumstances. Otherwise, the entire test should be rejected, for the lack of legal

118 In this sense, see M Senftleben, 'The International Three-Step Test: A Model Provision for EC Fair Use Legislation' (2010) 1(2) Journal of Intellectual Property, Information Technology and E-Commerce Law, 67; and M Senftleben, 'Comparative Approaches to Fair Use: An Important Impulse for Reforms in EU Copyright Law' in G B Dinwoodie (ed), Intellectual Property Law: Methods and Perspectives (Edward Elgar, 2014); C Geiger, 'The Role of the Three-Step Test in the Adaptation of Copyright Law to the Information Society' (January-March 2007) e-Copyright Bulletin.

119 The three-step test is known under a similar (but not identical) composition in numerous international agreements relating to copyright law and intellectual property, such as article $9(2)$ of the Berne Convention (for the right of reproduction), article 13 TRIPS (for all exploitation rights) (Marrakesh Agreement Establishing the World Trade Organization, opened for signature 15 April 1994, 1867 UNTS 3 (entered into force 1 January 1995), annex IC (Agreement on TradeRelated Aspects of Intellectual Property Rights)), and article 10 and article 16, respectively, of the WIPO treaties concerning copyright law (World Intellectual Property Organization Copyright Treaty, opened for signature 20 December 1996, 36 ILM 65, entered into force 6 March 2002, 'WIPO Copyright Treaty') and the right of the performers or producers of phonograms (World Intellectual Property Organization Performances and Phonograms Treaty ('WPPT'), opened for signature 20 December 1996, 36 ILM 76, entered into force 20 May 2002). Further on this, see C Geiger, D Gervais, and M Senftleben, 'The Three-Step-Test Revisited: How to Use the Test's Flexibility in National Copyright Law' (2014) 29(3) American University International Law Review 581.

120 This is especially the case since some legislatures have implemented the three-step test in their national copyright law (in France for example in article L 122-5 IPC). Since then, it is incontestable that the three-step test will be used by courts when applying the exceptions (see C Geiger, 'From Berne to National Law, via the Copyright Directive: The Dangerous Mutations of the Three-Step Test' (2007) European Intellectual Property Review 486).

121 Anyhow, it seems that the ECJ in its Infopaq decision of 16 July 2009 understood the threestep test of article 5(5) as implying a restrictive interpretation of copyright exceptions (Infopaq International $v$ Danske Dagblades Forening (C-5/08) [2009] ECJ, Judgment of the Court (Fourth Chamber) of 16 July 2009 ECR I-06569, [56]-[58]). 
certainty cannot, on the one hand, be acceptable when it benefits the right owner and, on the other hand, be considered unacceptable if it is of advantage to the user.

In fact, the third step of the test deals with the justification that underlies the limitation. Therefore, it is by far the most important part of the test. According to it, application of limits to copyright must not be to any 'unjustified' disadvantage of the copyright owner. The rationale is that the author should not be in the position to control all sorts of use of his work, but he has to tolerate certain interferences as long as they are justified by values that are superior to the copyright owner's interests. ${ }^{122}$ This formula will enable the judge to apply a sort of control of proportionality such as is used in cases of conflict between different fundamental rights. ${ }^{123}$ In such cases, the judge takes into consideration the justification underlying the limitation concerned in order to achieve a refined balance of the different interests and fundamental rights involved. Thus combining the security of the closed system of exceptions with the flexibility of the fair-use method, this approach would have an interesting outcome: henceforth, the judge would be able to adjust the application of limitations not only with regard to the economic interests of the right holder but also by taking into consideration divergent interests of the users, as well as the interests of the author in case they are different from those of the exploiter. ${ }^{124}$ Unfortunately, in some cases the application of the three-step test by the courts has been rather restrictive, ${ }^{125}$ because the criteria have been interpreted to the clear advantage of the right holders. Nevertheless,

122 The Constitutional Court of Germany clarified it very clearly in its 'Schoolbook' decision, 7 July 1971 (1972) Gewerblicher Rechtsschutz und Urheberrecht.

123 M Senftleben, Copyright, Limitations and the Three-Step Test (Kluwer, 2004), 226; S Dusollier, 'L'encadrement des exceptions au droit d'auteur par le test des trois étapes' (2005) Intellectuele Rechten - Droit Intellectuels 213, 221; C Geiger, 'The Three-Step Test, A Threat to a Balanced Copyright Law?' (2006) 37 International Review of Intellectual Property and Competition Law 683, 696; T Sinodinou, 'Voyage des sources du test des trois étapes aux sources du droit d'auteur' (2007) (30) Revue Lamy Droit De L'immatériel, at 67.

124 In fact, the authors and the exploiters may have very different interests, especially when it comes to the adoption of technical protection measures. In this sense, it is important to consult the wording of the three-step test to clarify the perspective. As a matter of fact, in the Berne Convention and the WIPO Treaty of 1996, it is 'the legitimate interests of the author' that have to be taken into account, while in the TRIPS Agreement and in the Directive it is 'the legitimate interests of the rightholder'. If it is really the author who is at the centre of interest, as is so often declared in author's-right countries, it should be the interests of the authors that prevail over those of the right holders when interpreting the test.

125 French Supreme Court, $1^{\text {st }}$ Civil Division, 28 February 2006, (2006) 37 International Review of Intellectual Property and Competition Law 760, with comment by C Geiger, 683. 
in the future judges will be free to interpret the test in another way. In this way, they could draw inspiration from the suggestions of some scholars who have proposed other interpretations ${ }^{126}$ in order to render the three-step test an efficient instrument of flexibility, so that limitations provided by the legal statutes could finally be interpreted more extensively.

\subsection{Securing the material interests of creators: A crucial aspect of copyright as an access right}

Establishing copyright as an access right and a right to participate in the cultural life does not necessarily mean that this access will be for free. In fact, one essential feature of a copyright system conceived as an access right is that in the spirit of the international human rights provisions that secure access to culture, the material and moral interests of the creators are safeguarded. This certainly implies that the copyright system benefits the creators in a better way, meaning that they must participate more effectively in the exploitation of their works. How this can finally be reached is secondary. One could, of course, imagine a better contract law ${ }^{127}$ (with some mandatory rules, like the copyright contract rules of some European countries), but also an increase of statutory licences if these offer financially more favourable solutions for the creators than the exclusive right. ${ }^{128}$ This latter course has so far remained relatively unexplored and still requires

126 See Geiger, Gervais and Senftleben, above n 118; Senftleben, 'The International Three-Step Test', above n 117; and Senftleben, 'Comparative Approaches to Fair Use' above n 117; Geiger, above n 117; KJ Koelman, 'Fixing the Three-Step Test' (2006) European Intellectual Property Review 407.

127 See e.g. RM Hilty, 'Five Lessons About Copyright in the Information Society: Reaction of the Scientific Community to Over-Protection and What Policy Makers Should Learn' (2006) 53 Journal of the Copyright Society of the USA 127, 137.

128 See the very interesting article by J C Ginsburg, 'Fair Use for Free, or Permitted-but-Paid?' (2014) vol 29, Berkeley Technology Law Journal, 1384, favouring the development in the US of statutory licenses or privately negotiated accords within a statutory framework, as they can ensure that 'uses the legislator perceives to be in the public interest proceed free of the copyright owner's veto, but with compensation - in other words: permitted-but-paid'. According to this author, 'whichever method employed to set the rates for permitted-but-paid uses, the copyright law should ensure that authors share in any statutory or privately ordered remuneration scheme' (at 1446). 
closer investigation. ${ }^{129}$ In fact, from an international human rights perspective, neither the UDHR nor the ICESCR determine the way in which the protection of the relevant material and immaterial interests has to be achieved. There is no mention of the exclusive rights or even of property: that means that within the scope of these treaties, other means of protection are equally conceivable. ${ }^{130}$ This leaves countries a good deal of room to manoeuvre, while at the same time guaranteeing creators a just remuneration for their work, which makes these legal instruments particularly modern and flexible means of regulating intellectual property matters. ${ }^{131}$

In summary, the copyright regimes should secure that creators participate fairly in the earnings generated by the commercial exploitation of their creations. This does not have to be necessarily through the implementation of an exclusive property right. Legislators should have the freedom to choose the legal means to secure the right for creators to receive a fair remuneration for the commercial exploitation of their works. ${ }^{132}$

\section{Conclusion}

An investigation of the basis of intellectual property shows that the classical justifications have been displaced in favour of protection of investment and that the balance within the system is threatening to break in favour of the exploiters of IP rights. This conclusion is

129 Such ideas have in fact been formulated for the field of copyright. See Geiger, above $\mathrm{n}$ 80, 515; Geiger, above n 19, 318 et seq.; RM Hilty, 'Verbotsrecht vs. Vergütungsanspruch: Suche nach den Konsequenzen der tripolaren Interessenlage im Urheberrecht' in A Ohly et al (eds), Festschrift für Gerhard Schricker (Beck, 2005), 348 et seq. In the context of the levy for private copying, see also K Gaita and AF Christie, 'Principle or Compromise? Understanding the Original Thinking Behind Statutory License and Levy Schemes for Private Copying' (2004) Intellectual Property Quarterly 426; A Dietz, 'Continuation of the Levy System for Private Copying also in the Digital Era in Germany' (2003) Auteurs et Médias, 348 et seq.

130 The General Comment No 17 confirmed, for example, that IP protection, not excluding the property entitlement in the majority of cases, may still, under certain circumstances guided by public-interest considerations, be reduced to 'compensatory measures, such as payment of adequate compensation': CESCR, above n 28, [24]. See also Geiger, 'Fundamental Rights as Common Principles of European (and International) Intellectual Property Law', above n 74, 227. 131 See also in this sense, T Mylly, 'Intellectual Property and Fundamental Rights: Do they Interoperate?' in N Bruun (ed), Intellectual Property Beyond Rights (WSOY, 2005), 197; Geiger, 'Fundamental Rights as Common Principles of European (and International) Intellectual Property Law', above n 74, 227.

132 See Geiger, 'Statutory Licenses as an Enabler of Creative Uses', above n 111. 
not new, this 'paradigm shift' already having been stressed by the literature in the $1980 \mathrm{~s},{ }^{133}$ but no real conclusions were drawn at the time. Assuming, however, that the foundations of the system have changed, the same solutions cannot apply and establishing copyright as a 'right to access' rather than a 'right to forbid or sanction' has become absolutely necessary.

Of course, as we have seen, both the protection and access aspects of copyright are closely linked. However, the current overprotective tendencies might require an emphasis on cultural participation and on the inclusive function of copyright law in order to re-establish the fair balance of interests within the system. It is thus not without importance whether copyright is understood as a cultural right or as an investment-protection mechanism, and the massive rejection of intellectual property in the public opinion is a clear indicator of this. As we have shown, (re)conceiving IP, and in particular copyright, as an access right ${ }^{134}$ will help avoiding the privatisation of information by IP law ${ }^{135}$ and assure that cultural and scientific creations are still available for future innovations.

133 See e.g. A Dietz, 'Transformation of Authors' Rights, Change of Paradigm' (1988) 138 Revue Internationale du Droit d'Auteur, 22.

134 In this spirit, see the thematic report of December 2014 by the UN Special Rapporteur in the field of cultural rights, which is devoted to the issue of the impact of intellectual property regimes on the enjoyment of right to science and culture, as enshrined in particular in article 15 ICESCR (UN General Assembly, Report of the Special Rapporteur in the field of Cultural Rights, F Shaheed, Copyright Policy and the Right to Science and Culture, Human Rights Council, Twentyeighth session, A/HRC/28/57, 24 December 2014).

135 Further on this tendency, see Geiger, above $\mathrm{n} 8$. 
This text is taken from What if we could reimagine copyright?, edited by Rebecca Giblin and Kimberlee Weatherall, published 2017 by ANU Press, The Australian National University, Canberra, Australia. 